\title{
PENGARUH PENGUMUMAN PEMBELIAN KEMBALI SAHAM \\ (BUYBACK) TERHADAP ABNORMAL RETURN DAN VOLUME PERDAGANGAN SAHAM PADA PERUSAHAAN YANG TERDAFTAR DI BURSA EFEK INDONESIA
}

\begin{abstract}
Afni Eliana Saragih
Abstrak

Pengumuman buyback sebagai salah satu aksi korporasi emiten merupakan salah satu informasi yang penting bagi investor. Reaksi investor atas pengumuman aksi korporasi tersebut dilihat dari perubahan harga yang ditunjukkan oleh abnormal return dan volume perdagangan yang ditunjukkan dengan trading volume activity (TVA). Penelitian ini berbasis event study dengan pengumuman buyback sebagai event yang diteliti. Metode pengambilan sampel menggunakan simple random sampling dan diperoleh 54 sampel penelitian dari 74 populasi. Uji hipotesis dilakukan dengan uji one sample t-test untuk melihat pengaruh pengumuman buyback terhadap abnormal return dalam jangka pendek (11 hari di sekitar pengumuman) dan jangka waktu yang lebih panjang (enam bulan setelah pengumuman). Hasil penelitian menunjukkan bahwa terdapat abnormal return dan peningkatan volume perdagangan dalam jangka pendek dan jangka waktu yang lebih panjang.
\end{abstract}

Kata kunci: Buyback, Abnormal Return, Volume Perdagangan

\section{PENDAHULUAN}

Menurut teori sinyal (Baker et al., 2003), perusahaan melakukan buyback saham bermaksud untuk menyampaikan informasi yang positif bahwa prospek perusahaan akan baik di masa mendatang. Dasar teori sinyal adalah kondisi di mana manajer memiliki informasi yang lebih akurat akan nilai wajar perusahaan dibandingkan dengan pemegang saham. Asimetri informasi antara pemegang saham dengan manajer memungkinkan harga saham tidak menggambarkan nilai wajar perusahaan yang sebenarnya karena pemegang saham hanya memiliki akses terhadap informasi yang tersedia di publik. Membeli kembali saham yang beredar dapat memberikan sinyal bahwa harga saham di pasar saat ini lebih rendah dibandingkan nilai intrinsik perusahaan (undervalued). Tsetsekos et al., (1991) dalam Dixon et al., (2008) menyebutkan bahwa harga saham yang undervalued merupakan faktor penting yang mempengaruhi perusahaan untuk melakukan buyback saham.

Wensley et al. (1989) dalam Boudry et al. (2013) menulis beberapa motif perusahaan melakukan buyback saham, diantaranya: (1) Memberikan sinyal bahwa prospek perusahaan akan baik di masa mendatang atau 
memberikan sinyal bahwa manajer sebagai pihak insider yang mengetahui kondisi perusahaan mengetahui bahwa harga saham sedang undervalued (undervalued hypothesis); (2) Buyback saham merupakan metode yang secara potensial memberikan kemungkinan lebih bagi insider dalam hal kontrol perusahaan; (3) Untuk menyediakan saham untuk dijual kembali, misalnya untuk stock option plan; (4) Buyback saham dilakukan karena terdapat arus kas bebas dalam jumlah besar dan dipandang tidak ada investasi yang potensial bagi perusahaan; (5) Buyback saham sebagai substitusi terhadap pembayaran dividen, perusahaan dapat mengunakan buyback saham sebagai alternatif lain untuk mendistribusikan kas kepada pemegang saham karena tarif pajak dividen lebih tinggi dibandingkan dengan pajak yang dibebankan terhadap capital gain.

Beberapa hasil penelitian menunjukkan bahwa harga dan volume perdagangan saham akan naik jika perusahaan melakukan pembelian kembali saham yang beredar. Wang et al. (2013) menganalisis dampak pengumuman buyback saham di Taiwan dengan menguji pengaruhya terhadap abnormal return baik jangka panjang maupun jangka pendek. Hasil penelitiannya menunjukkan bahwa perusahaan yang melalukan buyback saham menunjukkan terdapat abnormal return yang positif. Hasil penelitian yang sama juga ditemukan oleh Lee et al.( 2010), Haw et al. (2011) dan Yook (2010). Hasil penelitian Chua (2010) menemukan terdapat abnormal return yang positif di sekitar pengumuman (jangka pendek) buyback. Reaksi harga saham yang positif tersebut mengkonfirmasi bahwa pengumuman buyback saham ditangkap sebagai berita baik (good news) di pasar. Hasil penelitian yang dilakukan oleh Ikenberry et al. (1995), Lee et al. (2005), Axelsson dan Brissman (2011) ditemukan adanya abnormal return yang postitif dalam jangka waktu yang lebih panjang, membuktikan adanya underreaction hypothesis karena pasar bereaksi secara lambat dalam jangka pendek. Hal ini karena pasar sedang menunggu pengumuman buyback saham tersebut direalisasi (Lakonishok dan Vermaelen, 1990; Ikenberry et al., 1996; Zhang, 2005).

Namun demikian, hasil penelitian terkait pengaruh buyback terhadap reaksi pasar tidak selalu konsisten. Seperti yang telah dijelaskan di atas penelitian yang dilakukan oleh Axelsson dan Brissman (2011) dan Wang et al., (2013) menemukan bahwa buyback berpengaruh positif terhadap abnormal return baik untuk jangka waktu yang lebih pendek (selama 10 hari) maupun untuk jangka waktu yang lebih panjang (selama 12 bulan). Hasil penelitian Chua (2010) menemukan terdapat abnormal return yang positif di sekitar pengumuman buyback (jangka waktu yang 
lebih pendek). Yook (2010) menemukan bahwa perusahaan yang mengumumkan buyback secara tidak teratur memperoleh abnormal return dalam jangka panjang dan hasil penelitian Lakonishok dan Vermaelen (1990) menunjukkan terdapat abnormal return dalam dua tahun setelah buyback dilakukan. Namun sebaliknya Jagannathan, Stephens dan Weisbach (2000) serta Paulsen (2011) menyatakan bahwa buyback tidak menambah nilai bagi pemegang saham.

Penelitian ini memberikan kontribusi dalam beberapa hal. Pertama, sesuai dengan saran penelitian Axelsson dan Brissman (2011) yang telah menguji pengaruh buyback terhadap abnormal return dalam jangka pendek dan jangka panjang, penelitian ini akan menambah variabel lain yaitu menguji pengaruh buyback terhadap volume perdagangan. Kedua, penelitian Axelsson dan Brissman (2011) tersebut menguji abnormal return selama 12 bulan. Oleh sebab itu penelitian ini akan membagi periode waktunya ke beberapa waktu pengamatan yaitu selama 3 bulan dan 6 bulan untuk melihat apakah terjadi perubahan abnormal return yang berbeda pada pengamatan yang berbeda. Selain itu jangka waktu pengamatan akan disesuaikan dengan kondisi di Indonesia. Sesuai dengan peraturan Bapepam XI.B.3, pembelian kembali saham hanya dapat dilakukan dalam jangka waktu paling lama 3 (tiga) bulan dan maksimal 18 bulan melalui peraturan XI.B.2 setelah keterbukaan informasi disampaikan ke publik. Ketiga, penelitian Axelsson dan Brissman (2011) tersebut dilakukan di Stockholm dengan karakteristik pasar yang berbeda dengan kondisi pasar di Indonesia.

Beberapa peneliti seperti Chua (2010), Yook (2010), Axelsson dan Brissman (2011) dan Wang et al. (2013) telah menunjukkan bahwa buyback saham dapat meningkatkan harga dan volume perdagangan saham, yang tentunya bermanfaat bagi perusahaan maupun investor. Berdasarkan fenomena pengumuman buyback yang telah dijelaskan sebelumnya, penelitian ini bertujuan untuk menguji pengaruh pengumuman buyback terhadap reaksi pasar yang ditunjukkan dengan abnormal return dan peningkatan volume perdagangan. Penelitian terdahulu banyak dilakukan di negara-negara dengan volume dan jumlah perdagangan sahamnya dalam jumlah yang sangat besar dan sangat aktif. Peneliti ingin menguji apakah hal yang sama terjadi di Indonesia dengan kondisi pasar modal yang berbeda. 


\section{TINJAUAN PUSTAKA DAN PENGEMBANGAN HIPOTESIS}

\section{Telaah Teori}

\section{a. Efficient Market Hypothesis}

Secara formal pasar modal yang efisien didefenisikan sebagai pasar yang harga sekuritas-sekuritasnya telah mencerminkan semua informasi yang relevan. Semakin cepat informasi baru tercermin pada harga sekuritas, semakin efisien pasar modal tersebut. Dengan demikian akan sangat sulit bagi para investor untuk memperoleh tingkat keuntungan di atas normal secara konsisten dengan melakukan transaksi perdagangan di bursa efek. Tingkat keuntungan di atas normal diperoleh apabila tingkat keuntungan yang direalisasi lebih tinggi dibandingkan tingkat keuntungan ekuilibrum. Efisiensi dalam artian ini sering juga disebut sebagai efisiensi secara informasi (Husnan, 2005).

Pada pasar yang kompetitif, harga ekuilibrum suatu aktiva ditentukan oleh tawaran yang tersedia dan permintaan agrerat. Jika suatu informasi baru yang relevan masuk ke pasar yang berhubungan dengan suatu aktiva, informasi ini akan digunakan untuk menganalisis dan menginterpretasikan nilai dari aktiva yang bersangkutan. Akibatnya adalah kemungkinan pergeseran ke harga ekuilibrum yang baru. Harga ekulibrum ini akan tetap bertahan sampai suatu informasi baru lain mengubahnya kembali ke harga ekuilibrum baru.

Jika pasar bereaksi terhadap suatu informasi untuk mencapai harga keseimbangan yang baru yang sepenuhnya mencerminkan informasi yang tersedia, maka kondisi pasar seperti ini disebut dengan pasar efisien. Dengan demikian terdapat hubungan antara teori pasar modal yang menjelaskan tentang keadaan ekuilibrum dengan konsep pasar efisien yang mencoba menjelaskan bagaimana pasar memproses informasi untuk menuju ke posisi ekuilibrum yang baru. Efisiensi pasar yang demikian disebut denan efisiensi pasar secara informasi (Informationally Efficient Market) yaitu bagaimana pasar bereaksi terhadap informasi yang tersedia (Jogiyanto, 2012). Faktor utama mengukur pasar yang efisien adalah melihat hubunga antara harga sekuritas dengan informasi.

\section{b. Teori Sinyal}

Secara umum, sinyal diartikan sebagai isyarat yang dilakukan oleh perusahaan yaitu manajer kepada pihak lain yang di luar perusahaan seperti investor dan pemangku kepentingan lainnya. Sinyal ini dimaksudkan untuk menyiratkan sesuatu dengan harapan penilaian pasar atau pihak eksternal akan perusahaan akan berubah. Artinya sinyal yang dipilih harus 
mengandung informasi agar mampu mengubah penilaian pihak eksternal terhadap perusahaan (Gumanti, 2009).

Jika pengumuman tersebut mengandung nilai positif, maka diharapkan pasar akan bereaksi pada waktu pengumuman tersebut diterima oleh pasar. Reaksi pasar ditunjukkan dengan adanya perubahan volume perdagangan saham. Pada waktu informasi diumumkan dan semua pelaku pasar sudah menerima informasi tersebut, pelaku pasar terlebih dahulu menginterpretasikan dan menganalisis informasi tersebut sebagai sinyal baik (good news) atau sinyal buruk (bad news). Dalam penelitiannya, Baker et al., 2003 menuliskan bahwa dasar teori sinyal adalah kondisi di mana manajer memiliki informasi yang lebih akurat akan nilai wajar perusahaan dibandingkan dengan pemegang saham.

Teori sinyal juga menjelaskan mengapa manajer mempunyai dorongan untuk memberikan informasi laporan keuangan kepada pihak eksternal, karena terdapat asimetri informasi antara manajer dengan stakeholder yang ada di luar perusahaan. Manajer sebagai agen mengetahui lebih banyak informasi mengenai perusahaan dan prospek perusahaan di masa yang akan datang dibandingkan dengan stakeholder (investor, kreditor, pemerintah).

Asquith dan Mullins (1986) mengidentifikasi adanya abnormal return yang positif sehubungan dengan pengumuman buyback saham. Harga saham akan meningkat di sekitar pengumuman, sesuai dengan asimetri informasi atau signaling hypothesis, yang menyatakan bahwa perusahaan akan melalukan buyback ketika manajer memiliki informasi privat (private information) yaitu harga saham dinilai terlalu rendah oleh pasar. Pengumuman buyback memberikan sinyal bahwa manajer mengetahui bahwa harga saham perusahaan sedang undervalued, sehingga harga saham akan naik setelah pengumuman ini dirilis. Selain itu pengumuman buyback dapat mengarahkan pada redistribution kekayaan dari pemegang saham yang tidak memiliki informasi kepada pemegang saham yang memiliki informasi.

Wang et al. (2013) menganalisis dampak pengumuman buyback saham di Taiwan dengan menguji pengaruhya terhadap abnormal return baik jangka panjang maupun jangka pendek. Hasil penelitiannya menunjukkan bahwa perusahaan yang melalukan buyback saham menunjukkan terdapat abnormal return yang positif. Hasil penelitian yang sama juga ditemukan oleh Lee et al.( 2010), Haw et al. (2010) dan Yook (2010). Hasil penelitian Chua (2010) menemukan terdapat abnormal return yang positif di sekitar pengumuman (jangka pendek) buyback. 
Reaksi harga saham yang positif tersebut mengkonfirmasi bahwa pengumuman buyback saham ditangkap sebagai berita baik (good news) di pasar. Hasil penelitian yang dilakukan oleh Ikenberry et al. (1995), Lee et al. (2005), Axelsson dan Brissman (2011) ditemukan adanya abnormal return yang postitif dalam jangka waktu yang lebih panjang, membuktikan adanya underreaction hypothesis karena pasar bereaksi secara lambat dalam jangka pendek. Hal ini karena pasar sedang menunggu pengumuman buyback saham tersebut direalisasi (Ikenberry et al., 1995; Lakonishok dan Vermaelen, 1990; Zhang, 2005).

\section{Pengembangan Hipotesis}

\section{a. Pengaruh Pengumuman Buyback Terhadap Abnormal Return Dalam Jangka Pendek}

Pengumuman buyback merupakan salah satu informasi publik yang penting bagi investor karena berkaitan dengan perusahaan dan mempengaruhi harga dan volume perdagangan saham. Pengumuman buyback merupakan event dalam pengujian pasar efisien bentuk semi kuat karena sumber informasinya adalah informasi publik (Jogiyanto, 2012). Pengumuan buyback dipandang mempunyai kandungan informasi apabila ada reaksi harga saham dan volume perdagangan yang muncul dari pergerakan harga saham atau adanya perbedaan rata-rata abnormal return sebelum dan sesudah pengumumuman. Apabila terdapat abnormal return yang positif di sekitar pengumuman buyback atau adanya perbedaan antara sebelum dan sesudah pengumuman buyback maka pasar dapat dinyatakan efisien dalam bentuk semi kuat, namun apabila tidak ada perbedaan yang signifikan di sekitar pengumuman buyback atau tidak terdapat abnormal return yang positif di sekitar pengumuman makan pasar saham Indonesia dinyatakan dalam kondisi tidak efisien.

Asimetri informasi antara pemegang saham dengan manajer memungkinkan harga saham tidak menggambarkan nilai wajar perusahaan yang sebenarnya karena pemegang saham hanya memiliki akses terhadap informasi yang tersedia di publik. Membeli kembali saham yang beredar dapat memberikan sinyal bahwa harga saham di pasar saat ini lebih rendah dibandingkan nilai intrinsik perusahaan (Baker et al., 2003). Menurut teori sinyal, perusahaan melakukan pembelian kembali saham yang beredar bermaksud untuk menyampaikan informasi yang positif akan prospek perusahaan di masa mendatang. Investor memandang pengumuman buyback sebagai 'good news' dan akan bereaksi secara positif. Jika investor memandang optimis akibat sinyal positif dari informasi yang 
diterima, maka investor akan menambah jumlah pembelian yang terjadi dan akan menurunkan penawaran di pasar sehingga harga akan terdorong naik (Sharpe, Alexander dan Bailey, 2005 dalam Yanti, 2012). Penelitian Axelsson dan Brissman (2011), Wang et al., (2013) telah menunjukkan bahwa terdapat abnormal return pada tanggal pengumuman dan beberapa hari setelah pengumuman. Berdasarkan uraian di atas dapat dirumuskan hipotesis sebagai berikut:

H1 : Pengumuman buyback berpengaruh positif terhadap abnormal return dalam jangka pendek.

\section{b. Pengaruh Pengumuman Buyback Terhadap Abnormal Return Dalam Jangka Panjang}

Berdasarkan pasar efisiensi bentuk kuat, ketika informasi masuk ke pasar maka segera pasar akan bereaksi atas informasi tersebut. Dengan demikian diperkirakan harga saham akan sesegera mungkin mengalami penyesuaian. Namun di sisi lain mungkin pasar akan rasional menunggu aksi korporasi buyback benar-benar direalisasikan oleh perusahaan (actual buyback). Abnormal return mungkin masih diperoleh beberapa waktu setelah pengumuman buyback karena ada investor yang terlambat mendapat informasi sehingga terlambat untuk mengambil keputusan investasi.

Beberapa peneliti seperti Ikenberry et al., (1995), Wang et al., (2013) menemukan bahwa terdapat abnormal return yang positif pada perusahaan yang melakukan pembelian saham kembali (buyback saham) dalam jangka panjang. Abnormal return yang positif mengimplikasikan bahwa pasar tidak dengan segera merespon informasi yang dirilis perusahaan. Mereka menyatakan bahwa pasar memandang pengumuman buyback saham dengan skeptis dan pasar akan bereaksi secara lambat atas pengumuman tersebut. Hal ini disebabkan karena para investor sedang menunggu sampai perusahaan benar-benar merealisasikan aksi korporasi tersebut.

Berdasarkan teori dan hasil penelitian sebelumnya maka hipotesis kedua dirumuskan sebagai berikut:

$\mathrm{H} 2$ : Pengumuman buyback berpengaruh positif terhadap abnormal return dalam jangka waktu yang lebih panjang.

\section{c. Pengaruh Pengumuman Buyback Terhadap Volume Perdagangan Dalam Jangka Pendek}


Informasi yang dipublikasikan sebagai suatu pengumuman akan memberikan signal bagi investor dalam pengambilan keputusan investasi (Jogiyanto, 2012). Jika pengumuman tersebut mengandung nilai positif, maka diharapkan pasar akan bereaksi pada waktu pengumuman tersebut diterima oleh pasar. Reaksi pasar ditunjukkan dengan adanya perubahan volume perdagangan saham.

Pada waktu informasi diumumkan dan semua pelaku pasar sudah menerima informasi tersebut, pelaku pasar terlebih dahulu menginterpretasikan dan menganalisis informasi tersebut sebagai signal baik (good news) atau signal buruk (bad news). Hasil dari interpretasi informasi tersebut akan mempengaruhi permintaan dan penawaran dari investor. Jika banyak investor berpandangan pesimis akibat bad news dari informasi yang diterima, maka ia akan mengurangi jumlah pembelian yang terjadi dan akan menambah penawaran di pasar. Sebaliknya jika investor memandang optimis akibat good news dari informasi yang diterima, maka ia akan menambah jumlah pembelian yang terjadi dan akan menurunkan penawaran di pasar (Sharpe, Alexander dan Bailey, 2005 dalam Yanti, 2012). Pengumuman buyback yang dipandang sebagai good news akan meningkatkan permintaan sehingga terjadi peningkatan volume perdagangan. Ada tidaknya pengaruh pengumuman buyback dapat dilihat dari ada tidaknya rata-rata trading volume activity di sekitar tanggal pengamatan. berikut :

Berdasarkan uraian di atas dapat dirumuskan hipotesis sebagai

H3 : Pengumuman buyback berpengaruh positif terhadap volume perdagangan saham dalam jangka pendek.

\section{d. Pengaruh Pengumuman Buyback Terhadap Volume Perdagangan Dalam Jangka Panjang}

Menurut Kim dan Verrecchia (1991) volume perdagangan merupakan suatu fungsi peningkatan dari perubahan harga absolut, dimana harga merefleksikan tingkat informasi. Pengumuman buyback yang dipandang sebagai sinyal positif akan meningkatkan harga saham, juga akan mempengaruhi volume perdagangan saham. Perdagangan saham dapat terjadi jika para investor mempunyai kecermatan yang berbeda terhadap pengungkapan informasi yang mereka peroleh. Perbedaan kecermatan tersebut dapat diartikan adanya investor yang terlambat menerima informasi yang dipublikasikan atau sedang menunggu 
perusahaan merealisasikan pengumuman tersebut. Dengan demikian akan terdapat volume perdagangan saham dalam jangka waktu yang lebih panjang.

Selanjutnya hipotesis keempat dirumuskan sebagai berikut:

H4 : Pengumuman buyback berpengaruh positif terhadap volume perdagangan saham dalam jangka waktu yang lebih panjang.

Berdasarkan tinjauan dan konsep teori tentang variabel penelitian dan didukung oleh telaah literatur penelitian sebelumnya, maka kerangka pemikiran teoritis dalam penelitian ini dapat digambarkan dengan model berikut.

\section{Gambar 1. Model Penelitian}

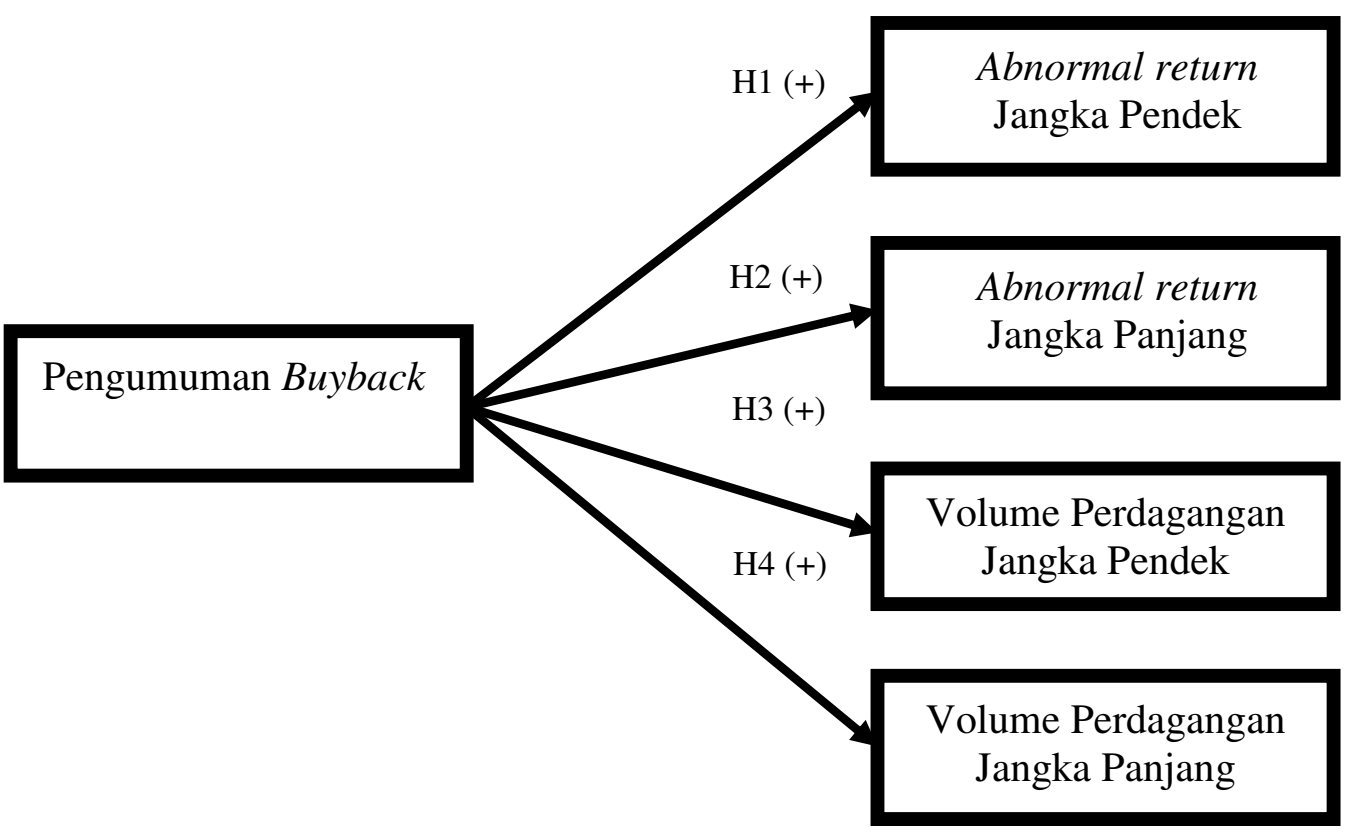

\section{METODE PENELITIAN}

\section{Populasi dan Sampel}

Populasi penelitian ini adalah seluruh perusahaan yang mengumumkan akan membeli kembali saham mereka yang beredar dan terdaftar di Bursa Efek Indonesia tahun 2009-2013. Tehnik pengambilan sampel dalam penelitian ini adalah menggunakan tehnik pengambilan 
sampel acak sederhana. Desain pengambilan sampel ini dipilih karenan generalisasi temuan pada seluruh populasi merupakan tujuan penelitian ini.

\section{Operasional Variabel}

\begin{tabular}{|c|c|c|c|}
\hline Variabel & Defenisi & Indikator & Skala \\
\hline $\begin{array}{l}\text { Pengumuman } \\
\text { Buyback }\end{array}$ & $\begin{array}{l}\text { Pengumuman oleh } \\
\text { perusahaan atas aksi } \\
\text { korporasi rencana } \\
\text { membeli kembali } \\
\text { saham perusahaan } \\
\text { yang beredar }\end{array}$ & $\begin{array}{l}\text { Tanggal } \\
\text { pengumuman } \\
\text { buyback oleh } \\
\text { perusahaan } \\
\text { yang diperoleh } \\
\text { dari laman IDX }\end{array}$ & Nominal \\
\hline $\begin{array}{l}\text { Abnormal } \\
\text { Return }\end{array}$ & $\begin{array}{l}\text { Reaksi pasar yang } \\
\text { menunjukan } \\
\text { perubahan harga atas } \\
\text { suatu pengumuman } \\
\text { dengan mengurangkan } \\
\text { return realisasi dengan } \\
\text { return ekspektasi }\end{array}$ & $\begin{array}{l}A R_{i t}=R_{i t} \\
-E\left(R_{i t}\right)\end{array}$ & Rasio \\
\hline $\begin{array}{l}\text { Volume } \\
\text { Perdagangan }\end{array}$ & $\begin{array}{l}\text { Reaksi pasar yang } \\
\text { menunjukkan jumlah } \\
\text { tindakan atau } \\
\text { perdagangan investor }\end{array}$ & TVAit $=\frac{\mathrm{Vi}, \mathrm{t}}{\mathrm{Vm}, \mathrm{t}}$ & Rasio \\
\hline
\end{tabular}

\section{Pengujian Hipotesis}

\section{Abnormal Return}

Pengujian statistik terhadap abnormal return adalah untuk melihat signifikansi abnormal return yang ada dalam periode peristiwa. Teknik pengujian yang dilakukan dengan uji beda dengan langkah sebagai berikut:

a. Hipotesis pertama dan kedua $=\mathrm{H} 1$ dan $\mathrm{H} 2$ : CAAR $>0$

Kriteria pengujian :

$\mathrm{P}$ value $<0,05: \mathrm{H} 1$ dan $\mathrm{H} 2$ diterima

$\mathrm{P}$ value $>0,05: \mathrm{H} 1$ dan $\mathrm{H} 2$ ditolak

b. Menghitung nilai t dengan menggunakan program IBM SPSS.

c. Membandingkan nilai $t$ dengan nilai t tabel.

\section{Volume Perdagangan}

Pengujian statistik terhadap volume perdagangan saham adalah untuk melihat signifikansi volume perdagangan yang ada dalam periode jendela. Teknik pengujian dilakukan dengan uji beda dengan langkah: 
a. Hipotesis ketiga dan keempat $=\mathrm{H} 3$ dan $\mathrm{H} 4$ : CATVA $>0$

Kriteria pengujian :

$\mathrm{P}$ value $<0,05: \mathrm{H} 3$ dan $\mathrm{H} 4$ diterima

$\mathrm{P}$ value $>0,05: \mathrm{H} 3$ dan $\mathrm{H} 4$ ditolak

b. Menghitung nilai $t$ dengan menggunakan program IBM SPSS.

c. Membandingkan nilai t hitung dengan nilai $t$ tabel.

\section{HASIL PENELITIAN DAN PEMBAHASAN}

Objek penelitian ini adalah seluruh emiten yang listing di Bursa Efek Indonesia. Pengambilan sampel dilakukan dengan menggunakan tehnik pengambilan sampel acak sederhana. Adapun populasi emiten yang mengumumkan buyback sepanjang penelitian ini adalah 74 emiten. Namun beberapa dari populasi tersebut akan dikeluarkan dari penelitian karena tidak memenuhi data yang dibutuhkan. Dengan demikian setelah melakukan penyesuaikan terhadap kriteria penelitian yang telah ditetapkan, diperoleh jumlah sampel sebanyak 54 emiten.

1. Hasil Uji Hipotesis

a. Pengumuman Buyback Terhadap Abnormal Return Dalam Jangka Pendek

Tabel 1

Hasil Uji Hipotesis 1

\begin{tabular}{|l|r|r|r|r|l|}
\hline \multicolumn{7}{|c|}{ One-Sample Test } \\
\hline & \multicolumn{1}{|c|}{$T$} & Df & $\begin{array}{c}\text { Sig. }(2- \\
\text { tailed })\end{array}$ & t-tabel & Keterangan \\
\hline $\mathrm{T}+5$ & -1.089 & 53 & 0.281 & 1.6741 & Tidak signifikan \\
\hline $\mathrm{T}+4$ & 0.655 & 53 & 0.515 & 1.6741 & Tidak signifikan \\
\hline $\mathrm{T}+3$ & 2.210 & 53 & 0.031 & 1.6741 & Signifikan \\
\hline $\mathrm{T}+2$ & 2.089 & 53 & 0.042 & 1.6741 & Signifikan \\
\hline $\mathrm{T}+1$ & 2.164 & 53 & 0.035 & 1.6741 & Signifikan \\
\hline $\mathrm{T}+0$ & 1.111 & 53 & 0.272 & 1.6741 & Tidak signifikan \\
\hline $\mathrm{T}-1$ & 0.202 & 53 & 0.841 & 1.6741 & Tidak signifikan \\
\hline $\mathrm{T}-2$ & -0.278 & 53 & 0.782 & 1.6741 & Tidak signifikan \\
\hline $\mathrm{T}-3$ & 0.059 & 53 & 0.953 & 1.6741 & Tidak signifikan \\
\hline $\mathrm{T}-4$ & 2.521 & 53 & 0.015 & 1.6741 & Signifikan \\
\hline $\mathrm{T}-5$ & -0.305 & 53 & 0.761 & 1.6741 & Tidak signifikan \\
\hline CAAR & $\mathbf{3 . 4 7 0}$ & $\mathbf{5 3}$ & $\mathbf{0 . 0 0 1}$ & $\mathbf{1 . 6 7 4 1}$ & Signifikan \\
\hline
\end{tabular}


Hipotesis pertama telah dirumuskan bahwa terdapat abnormal return atas pengumuman buyback dalam jangka pendek dilihat dari Cummulative Avarage Abnormal return lebih besar dari $0(C A A R>0)$ dan nilai t-hitung>t-tabel. Tampak dari tabel 4.6, nilai CAAR lebih besar dari 0 (CAAR 3.091634>0) dan dari tabel 4.7 tampak bahwa nilai t-hitung (3.470) lebih besar dibandingkan dengan t-tabel 1.7641 dan signifikan pada level $5 \%(0.001<0.05)$. Secara keseluruhan disimpulkan bahwa terdapat pengaruh pengumuman buyback terhadap abnormal return dalam jangka pendek yang ditunjukkan dengan nilai CAAR yang positif dan signifikan. Dengan demikian dapat disimpulkan bahwa hipotesis pertama diterima.

Penerimaan hipotesis pertama membuktikan bahwa pengumuman buyback memiliki pengaruh terhadap abnormal return saham perusahaan. Ditandai dengan terdapat abnormal return yang positif dan signifikan. Artinya harga saham perusahaan setelah pengumuman meningkat sehingga terdapat tambahan kekayaan bagi investor. Selain itu, dapat dibuktikan bahwa pengumuman buyback dapat menaikkan harga saham yang undervalued. Tabel 4.6 menunjukkan bahwa terdapat abnormal return yang negatif pada pengamatan sebelum pengumuman buyback dan didukung oleh hasil uji hipotesis pada tabel 4.7, nilai abnormal return yang negatif berarti harga saham perusahaan benar sedang rendah (undervalued) sebelum pengumuman buyback. Sesuai dengan hasil penelitian Baker et al., (2003) menyebutkan bahwa perusahaan akan mengumumkan buyback ketika harga saham sendang rendah (undervalued). Dengan demikian pengumuman buyback dapat menjadi alternatif bagi perusahaan untuk menaikkan harga saham. Hasil pengamatan tersebut dapat diterjemahkan bahwa para pelaku pasar mampu menerima sinyal informasi yang diberikan oleh perusahaan, dalam hal ini pengumuman buyback, dengan harapan akan mendapat return yang menguntungkan dari adanya transaksi tersebut. Temuan ini juga sejalan dengan temuan Lee et al., (2010) bahwa manager mengumumkan buyback dalam rangka meningkatkan harga saham yang pada akhirnya dapat meningkatkan kekayaan investor.

Teori sinyal yang menyatakan bahwa perusahaan cenderung melakukan buyback karena manajer mengetahui bahwa saham perusahaan dinilai terlalu rendah di pasar dibandingkan dengan nilai sebenarnya (undervalued). Manajer yang mengetahui kondisi tersebut akan mengumumkan buyback saham untuk mengurangi adanya asimetri informasi di antara manajemen dengan investor. Kurangnya informasi akan ditanggap dengan pesimis oleh investor karena membentengi diri dari 
risiko. Dengan demikian dapat ditemui bahwa buyback memiliki kandungan informasi yang menguntungkan (good news) bagi pemegang saham, sehingga abnormal return saham akan cenderung bergerak ke arah positif, sejalan dengan teori sinyal yang menyatakan bahwa informasi yang dianggap menguntungkan akan memberikan reaksi pasar yang positif.

\section{b. Pengumuman Buyback Terhadap Abnormal Return Dalam Jangka Waktu yang Lebih Panjang}

Tabel 2

Hasil Uji Hipotesis 2

\begin{tabular}{|l|r|r|r|r|l|}
\hline Date & \multicolumn{1}{|c|}{$t$} & $D f$ & $\begin{array}{c}\text { Sig. (2- } \\
\text { tailed) }\end{array}$ & t-tabel & \multicolumn{1}{|l|}{ Keterangan } \\
\hline $\mathrm{T}+30$ & 3.123 & 19 & 0.006 & 1.7291 & Signifikan \\
\hline $\mathrm{T}+60$ & 2.009 & 19 & 0.059 & 1.7291 & Signifikan \\
\hline $\mathrm{T}+90$ & 1.291 & 19 & 0.212 & 1.7291 & Tidak signifikan \\
\hline $\mathrm{T}+120$ & 0.038 & 19 & 0.970 & 1.7291 & Tidak signifikan \\
\hline $\mathrm{T}+150$ & 3.842 & 19 & 0.001 & 1.7291 & Signifikan \\
\hline $\mathrm{T}+180$ & 2.187 & 19 & 0.041 & 1.7291 & Signifikan \\
\hline CAAR & $\mathbf{4 . 7 1 3}$ & $\mathbf{1 9}$ & $\mathbf{0 . 0 0 0}$ & $\mathbf{1 . 7 2 9 1}$ & Signifikan \\
\hline
\end{tabular}

Tampak dari tabel 4.8 bahwa terdapat CAAR yang positif yaitu 15,37 dan lebih besar dari 0. Dengan demikian dapat dinyatakan bahwa terdapat pengaruh pengumuman buyback terhadap abnormal return yang positif. Hipotesis kedua seperti yang telah dirumuskan bahwa terdapat abnormal return atas pengumuman buyback dalam jangka waktu yang lebih panjang dilihat dari nilai CAAR yang lebih besar dari nol (CAAR $>0$ ) dan signifikan pada level 5\%. Tabel 4.10 telah mengunjukkan nilai CAAR yang positif yaitu 15.37. Selanjutnya tabel 4.11 menunjukkan nilai t-hitung (4.713) yang lebih besar dibandingkan t-tabel (1.7291) dan tingkat signifikansi (0.000) yang lebih kecil dari 0.05. Hal ini berarti bahwa masih terdapat abnormal return dalam jangka waktu yang lebih panjang atas pengumuman buyback. Dengan demikian dapat disimpulkan bahwa hipotesis kedua diterima. 
Temuan nilai CAAR yang positif dan signfikan sesuai dengan hasil penelitian Ikenberry et al (1995) yang menyatakan bahwa terdapat investor yang memandang pengumuman buyback dengan skeptis. Dengan demikian ada kemungkinan investor akan menunggu hingga pengumuman direalisasikan sehingga masih terdapat abnormal return yang positif dalam jangka waktu yang lebih panjang. Peraturan di Indonesia menyatakan bahwa batas waktu emiten merealisasikan aksi korporasi buyback adalah 3 (tiga) bulan bagi emiten yang mengacu pada prosedur Peraturan XI.B.3 dan 18 bulan bagi emiten yang mengumumkan buyback melalui prosedur Peraturan XI.B.2. Sejalan dengan kondisi tersebut investor mungkin menunggu hingga aksi korporasi buyback direalisasikan ditandai dengan masih terdapat abnormal return dalam jangka waktu yang lebih panjang.

Setelah menyampaikan keterbukaan informasi buyback kepada publik melalui pengumuman, emiten dapat langsung merealisasikannya. Realisasi buyback biasanya dilakukan tidak sekaligus, namun dilakukan perlahan-lahan dan sedikit demi sedikit, tergantung harga saham perusahaan di pasar. Seperti yang telah disebutkan di atas, di Indonesia pelaksanaan buyback dapat mengacu pada peraturan Bapepam XI.B.2 dan peraturan Bapepam XI.B.3. Emiten memiliki jangka waktu 18 bulan untuk merealisasikan pengumuman buyback melalui peraturan XI.B.2 dan tiga (3) bulan untuk peeraturan XI.B.3. Dengan demikian emiten dapat merealisasikan buyback dalam beberapa tahap dan dalam jumlah tertentu tergantung pada harga sahamnya di pasar. Jika harga di pasar sedang rendah maka emiten mungkin merealisasikannya dan akan berhenti jika harga pasar sudah kembali normal.

Nilai CAR sebesar 15,37 mendekati nilai CAR yang ditemukan oleh Ikenberry et al., (1995) yaitu rata-rata abnormal return 12,1 setelah buyback diumumkan. Pasar memperlakukan pengumuman buyback dengan skeptis yang pada akhirnya mengarah pada penyesuaian harga terjadi secara lambat dari waktu ke waktu disebut juga dengan Underreaction Hypothesis. Hasil penelitian Lakonishok dan Vermaelen (1990) terjadi tawar menawar (bargain) setidaknya selama 2 tahun. Delayed market reaction juga terjadi pada kasus event study lain seperti: Initial Public Offering (IPO) (Ritter, 1991), Merger (Agrawal, Jaffe, dan Mandelker, 1992), dan seasoned equity offerings (Loughran dan Ritter, 1995). Manager berharap bahwa setelah mengumumkan buyback mereka dapat membeli kembali saham dengan harga yang lebih murah demi kepentingan investor dalam jangka panjang. 


\section{c. Pengumuman Buyback Terhadap Volume Perdagangan Dalam Jangka Pendek}

Tabel 3

Hasil Uji Hipotesis 3

\begin{tabular}{|c|c|c|c|c|c|}
\hline \multicolumn{7}{|c|}{ One-Sample Test } \\
\hline Date & $\boldsymbol{T}$ & $\boldsymbol{d} \boldsymbol{f}$ & $\begin{array}{l}\text { Sig. (2- } \\
\text { tailed) }\end{array}$ & t-tabel & Keterangan \\
\hline $\mathrm{T}+5$ & 2.328 & 53 & 0.024 & 1.6741 & Signifikan \\
\hline $\mathrm{T}+4$ & 5.171 & 53 & 0.000 & 1.6741 & Signifikan \\
\hline $\mathrm{T}+3$ & 3.987 & 53 & 0.000 & 1.6741 & Signifikan \\
\hline $\mathrm{T}+2$ & 4.539 & 53 & 0.000 & 1.6741 & Signifikan \\
\hline $\mathrm{T}+1$ & 4.992 & 53 & 0.000 & 1.6741 & Signifikan \\
\hline $\mathrm{T}+0$ & 3.341 & 53 & 0.002 & 1.6741 & Signifikan \\
\hline $\mathrm{T}-1$ & 4.373 & 53 & 0.000 & 1.6741 & Signifikan \\
\hline $\mathrm{T}-2$ & 4.113 & 53 & 0.000 & 1.6741 & Signifikan \\
\hline $\mathrm{T}-3$ & 3.475 & 53 & 0.001 & 1.6741 & Signifikan \\
\hline $\mathrm{T}-4$ & 4.776 & 53 & 0.000 & 1.6741 & Signifikan \\
\hline $\mathrm{T}-5$ & 4.435 & 53 & 0.000 & 1.6741 & Signifikan \\
\hline CTVA & $\mathbf{5 . 4 1 5}$ & $\mathbf{5 3}$ & $\mathbf{. 0 0 0}$ & $\mathbf{1 . 6 7 4 1}$ & Signifikan \\
\hline
\end{tabular}

Seperti yang telah dijelaskan pada tabel 4.10 di atas bahwa nilai CATVA sebesar 1,943011>0 diikuti dengan uji one sample t-test pada tabel 4.11 menunjukkan nilai t-tabel 5.415 lebih besar dibandingkan dengan nilai t-hitung 1.6741 dan tingkat signifikansi (0.000) lebih kecil dari 0.05. Merujuk pada apa yang telah dirumuskan dalam hipotesis penelitian bahwa jika CATVA $>0$ dan nilai t-hitung lebih besar dibandingkan dengan t-tabel, maka dapat dinyatakan bahwa hipotesis diterima. Dengan demikian dapat disimpulkan bahwa hipotesis ketiga diterima.

Peningkatan volume perdagangan setelah pengumuman buyback mengindikasikan bahwa event tersebut dipandang informatif oleh investor sehingga mempengaruhi volume perdagangan saham di pasar modal. Volume perdagangan merupakan sebuah ukuran untuk melihat informasi yang terkandung dalam sebuah pengumuman publik. Hal ini sesuai dengan temuan Barron dan Karpoff (2004) bahwa volume perdagangan yang 
tinggi merupakan indikasi bahwa sebuah pengumuman mengandung informasi. Kondisi ini memberikan gambaran bahwa perusahaan berhasil memberikan sinyal positif ke pasar ditandai dengan respon positif investor yang dapat dilihat dari peningkatan volume perdagangan saham.

Ekspektasi investor berubah seiring dengan adanya informasi baru yang disampaikan ke pasar, dalam hal ini pengumuman buyback saham. Ekspektasi investor yang berubah tersebut ditunjukkan dengan reaksi positif terhadap perusahaan yang memiliki kinerja perusahaan yang baik. Mengumumkan pembelian kembali saham berarti akan ada arus kas keluar dari perusahaan yang disalurkan untuk membeli kembali saham yang beredar. Bagi para pemegang saham, buyback merupakan hal yang positif karena dengan cara buyback saham manajer berusaha meningkatkan kembali return yang akan diperoleh investor akibat penurunan harga saham. Bagi calon investor, pengumuman buyback saham dianggap sebagai sinyal dan momentum yang tepat dalam melakukan spekulasi terhadap saham perusahaan yang melakukan buyback. Ekspektasi calon investor bahwa saham perusahaan yang melakukan buyback akan mengalami peningkatan harga saham atau return yang tinggi ketika membeli saham dengan harga yang rendah (undervalued). Dengan demikian volume perdagangan yang diukur dari TVA juga akan meningkat secara signifikan.

\section{d. Pengumuman Buyback Terhadap Volume Perdagangan Dalam Jangka Panjang}

Tabel 4

Hasil Uji Hipotesis 4

One-Sample Test

\begin{tabular}{|l|c|c|c|c|c|}
\hline \multicolumn{1}{|c|}{ Date } & $\mathbf{t}$ & df & Sig. (2-tailed) & t-tabel & Keterangan \\
\hline $\mathrm{T}+30$ & 27.473 & 19 & 0.00 & 1.7291 & Signifikan \\
\hline $\mathrm{T}+60$ & 21.031 & 19 & 0.00 & 1.7291 & Signifikan \\
\hline $\mathrm{T}+90$ & 28.380 & 19 & 0.00 & 1.7291 & Signifikan \\
\hline $\mathrm{T}+120$ & 20.229 & 19 & 0.00 & 1.7291 & Signifikan \\
\hline $\mathrm{T}+150$ & 21.458 & 19 & 0.00 & 1.7291 & Signifikan \\
\hline $\mathrm{T}+180$ & 18.204 & 19 & 0.00 & 1.7291 & Signifikan \\
\hline CATVA & $\mathbf{4 5 . 9 7 1}$ & $\mathbf{1 9}$ & $\mathbf{0 . 0 0}$ & $\mathbf{1 . 7 2 9 1}$ & Signifikan \\
\hline
\end{tabular}


Seperti yang telah dijelaskan pada tabel 4.12 bahwa nilai CATVA sebesar $19.970>0$ diikuti dengan uji one sample t-test pada tabel 4.13 menunjukkan nilai t-tabel 45.971 lebih besar dibandingkan dengan nilai thitung 1.7291 dan tingkat signifikansi (0.000) lebih kecil dari 0.05 . Merujuk pada apa yang telah dirumuskan dalam hipotesis penelitian bahwa jika CATVA $>0$ dan nilai t-hitung lebih besar dibandingkan dengan t-tabel, maka dapat dinyatakan bahwa hipotesis diterima. Dengan demikian dapat disimpulkan bahwa hipotesis keempat diterima.

Kim and Verrecchia (1991) mengasumsikan bahwa investor adalah heterogen sehingga terjadi perbedaan revisi kepercayaan (belief) investor dan terdapat perbedaan akses terhadap informasi atau pengumuman. Dengan demikian ketika informasi baru dirilis ke pasar akan menyebkan terjadinya volume perdagangan. Malinowska (2010) dan Kim dan Verrecchia (1991) menunjukkan bahwa respon harga atas pengumuman adalah secara berangsur-angsur dan diikuti oleh volume perdagangan. Good news akan diikuti oleh return yang positif dan pembelian yang tinggi sesaat setelah pengumuman dirilis dan sebaliknya. Dengan demikian hasil penelitian Malinowska (2010) menunjukkan bahwa kehadiran informasi publik akan segera ditandai dengan penyesuaian harga diikuti atau bersamaan dengan peningkatan aktivitas perdagangan. Atau dengan kata lain ketika informasi baru dirilis ke publik maka akan diikuti respon harga yang signifikan dikombinasikan dengan tingginya volume perdagangan. Investor melakukan perdagangan untuk menyesuaikan atau mempertemukan perbedaan opini investor individual.

Pengumuman buyback yang dipandang sebagai sinyal positif akan meningkatkan harga saham, juga akan mempengaruhi volume perdagangan saham. Perdagangan saham dapat terjadi jika para investor mempunyai kecermatan yang berbeda terhadap pengungkapan informasi yang mereka peroleh. Perbedaan kecermatan tersebut dapat diartikan adanya investor yang terlambat menerima informasi yang dipublikasikan atau sedang menunggu perusahaan merealisasikan pengumuman tersebut. Dengan demikian masih terdapat volume perdagangan saham dalam jangka waktu yang lebih panjang.

\section{Pembahasan}

Penerimaan hipotesis pertama membuktikan bahwa pengumuman buyback memiliki pengaruh terhadap abnormal return saham perusahaan. Ditandai dengan terdapat abnormal return yang positif dan signifikan. Artinya harga saham perusahaan setelah pengumuman meningkat sehingga 
terdapat tambahan kekayaan bagi investor. Selain itu, dapat dibuktikan bahwa pengumuman buyback dapat menaikkan harga saham yang undervalued. Sesuai dengan hasil penelitian Baker et al., (2003) menyebutkan bahwa perusahaan akan mengumumkan buyback ketika harga saham sendang rendah (undervalued). Dengan demikian pengumuman buyback dapat menjadi alternatif bagi perusahaan untuk menaikkan harga saham. Hasil pengamatan tersebut dapat diterjemahkan bahwa para pelaku pasar mampu menerima sinyal informasi yang diberikan oleh perusahaan, dalam hal ini pengumuman buyback, dengan harapan akan mendapat return yang menguntungkan dari adanya transaksi tersebut. Temuan ini juga sejalan dengan temuan Lee et al., (2010) bahwa manager mengumumkan buyback dalam rangka meningkatkan harga saham yang pada akhirnya dapat meningkatkan kekayaan investor.

Teori sinyal yang menyatakan bahwa perusahaan cenderung melakukan buyback karena manajer mengetahui bahwa saham perusahaan dinilai terlalu rendah di pasar dibandingkan dengan nilai sebenarnya (undervalued). Manajer yang mengetahui kondisi tersebut akan mengumumkan buyback saham untuk mengurangi adanya asimetri informasi di antara manajemen dengan investor. Kurangnya informasi akan ditanggap dengan pesimis oleh investor karena membentengi diri dari risiko. Dengan demikian dapat ditemui bahwa buyback memiliki kandungan informasi yang menguntungkan (good news) bagi pemegang saham, sehingga abnormal return saham akan cenderung bergerak ke arah positif, sejalan dengan teori sinyal yang menyatakan bahwa informasi yang dianggap menguntungkan akan memberikan reaksi pasar yang positif.

Hipotesis kedua menemukan bahwa nilai CAAR positif dan signfikan sesuai dengan hasil penelitian Ikenberry et al (1995) yang menyatakan bahwa terdapat investor yang memandang pengumuman buyback dengan skeptis. Dengan demikian ada kemungkinan investor akan menunggu hingga pengumuman direalisasikan sehingga masih terdapat abnormal return yang positif dalam jangka waktu yang lebih panjang. Peraturan di Indonesia menyatakan bahwa batas waktu emiten merealisasikan aksi korporasi buyback adalah 3 (tiga) bulan bagi emiten yang mengacu pada prosedur Peraturan XI.B.3 dan 18 bulan bagi emiten yang mengumumkan buyback melalui prosedur Peraturan XI.B.2. Sejalan dengan kondisi tersebut investor mungkin menunggu hingga aksi korporasi buyback direalisasikan ditandai dengan masih terdapat abnormal return dalam jangka waktu yang lebih panjang. 
Setelah menyampaikan keterbukaan informasi buyback kepada publik melalui pengumuman, emiten dapat langsung merealisasikannya. Realisasi buyback biasanya dilakukan tidak sekaligus, namun dilakukan perlahan-lahan dan sedikit demi sedikit, tergantung harga saham perusahaan di pasar. Seperti yang telah disebutkan di atas, di Indonesia pelaksanaan buyback dapat mengacu pada peraturan Bapepam XI.B.2 dan peraturan Bapepam XI.B.3. Emiten memiliki jangka waktu 18 bulan untuk merealisasikan pengumuman buyback melalui peraturan XI.B.2 dan tiga (3) bulan untuk peeraturan XI.B.3. Dengan demikian emiten dapat merealisasikan buyback dalam beberapa tahap dan dalam jumlah tertentu tergantung pada harga sahamnya di pasar. Jika harga di pasar sedang rendah maka emiten mungkin merealisasikannya dan akan berhenti jika harga pasar sudah kembali normal.

Hipotesis ketiga menunjukkan bahwa volume perdagangan saham sebelum pengumuman lebih kecil dibandingkan dengan volume perdagangan setelah pengumuman disampaikan ke publik. Dengan demikian terjadi peningkatan volume perdagangan dari pengamatan setelah pengumuman buyback diketahui oleh pasar. Artinya pengumuman buyback memberikan manfaat yang baik bagi perusahaan yang ditunjukkan dengan adanya peningkatan volume perdagangan. Hasil penelitian yang positif dan signifikan mengindikasikan bahwa investor dapat menangkap sinyal yang diberikan oleh perusahaan. Melalui pengumuman buyback, harga saham akan meningkat sehingga return yang diterima investor juga akan positif yang pada akhirnya juga akan mempengaruhi aktivitas perdagangan di pasar modal.

Peningkatan volume perdagangan setelah pengumuman buyback mengindikasikan bahwa event tersebut dipandang informatif oleh investor sehingga mempengaruhi volume perdagangan saham di pasar modal. Volume perdagangan merupakan sebuah ukuran untuk melihat informasi yang terkandung dalam sebuah pengumuman publik. Hal ini sesuai dengan temuan Barron dan Karpoff (2004) bahwa volume perdagangan yang tinggi merupakan indikasi bahwa sebuah pengumuman mengandung informasi. Kondisi ini memberikan gambaran bahwa perusahaan berhasil memberikan sinyal positif ke pasar ditandai dengan respon positif investor yang dapat dilihat dari peningkatan volume perdagangan saham.

Ekspektasi investor berubah seiring dengan adanya informasi baru yang disampaikan ke pasar, dalam hal ini pengumuman buyback saham. Ekspektasi investor yang berubah tersebut ditunjukkan dengan reaksi positif terhadap perusahaan yang memiliki kinerja perusahaan yang baik. 
Mengumumkan pembelian kembali saham berarti akan ada arus kas keluar dari perusahaan yang disalurkan untuk membeli kembali saham yang beredar. Bagi para pemegang saham, buyback merupakan hal yang positif karena dengan cara buyback saham manajer berusaha meningkatkan kembali return yang akan diperoleh investor akibat penurunan harga saham. Bagi calon investor, pengumuman buyback saham dianggap sebagai sinyal dan momentum yang tepat dalam melakukan spekulasi terhadap saham perusahaan yang melakukan buyback. Ekspektasi calon investor bahwa saham perusahaan yang melakukan buyback akan mengalami peningkatan harga saham atau return yang tinggi ketika membeli saham dengan harga yang rendah (undervalued). Dengan demikian volume perdagangan yang diukur dari TVA juga akan meningkat secara signifikan.

Hipotesis keempat menyimpulkan bahwa masih terdapat peningkatan volume perdagangan dalam jangka waktu yang lebih panjang setelah pengumuman buyback disampaikan ke pasar. Kim and Verrecchia (1991) mengasumsikan bahwa investor adalah heterogen sehingga terjadi perbedaan revisi kepercayaan (belief) investor dan terdapat perbedaan akses terhadap informasi atau pengumuman. Dengan demikian ketika informasi baru dirilis ke pasar akan menyebkan terjadinya volume perdagangan. Malinowska (2010) dan Kim dan Verrecchia (1991) menunjukkan bahwa respon harga atas pengumuman adalah secara berangsur-angsur dan diikuti oleh volume perdagangan. Good news akan diikuti oleh return yang positif dan pembelian yang tinggi sesaat setelah pengumuman dirilis dan sebaliknya. Dengan demikian hasil penelitian Malinowska (2010) menunjukkan bahwa kehadiran informasi publik akan segera ditandai dengan penyesuaian harga diikuti atau bersamaan dengan peningkatan aktivitas perdagangan. Atau dengan kata lain ketika informasi baru dirilis ke publik maka akan diikuti respon harga yang signifikan dikombinasikan dengan tingginya volume perdagangan. Investor melakukan perdagangan untuk menyesuaikan atau mempertemukan perbedaan opini investor individual.

Pengumuman buyback yang dipandang sebagai sinyal positif akan meningkatkan harga saham, juga akan mempengaruhi volume perdagangan saham. Perdagangan saham dapat terjadi jika para investor mempunyai kecermatan yang berbeda terhadap pengungkapan informasi yang mereka peroleh. Perbedaan kecermatan tersebut dapat diartikan adanya investor yang terlambat menerima informasi yang dipublikasikan atau sedang menunggu perusahaan merealisasikan pengumuman tersebut. Dengan 
demikian masih terdapat volume perdagangan saham dalam jangka waktu yang lebih panjang.

\section{KESIMPULAN DAN SARAN}

\section{Kesimpulan}

Penelitian ini digunakan untuk menganalisis pengaruh pengumuman buyback terhadap abnormal return dan volume perdagangan di sekitar pengumuman dan dalam jangka waktu yang lebih panjang setelah pengumuman dirilis ke pasar. Berdasarkan hasil penelitian yang telah dilakukan terhadap keempat hipotesis yang diuji dengan menggunakan uji satu sisi one sample t-test dan uji beda diperoleh kesimpulan sebagai berikut:

1. Pengumuman buyback berpengaruh positif terhadap abnormal return dalam jangka pendek.

2. Pengumuman buyback berpengaruh positif terhadap abnormal return dalam jangka waktu yang lebih panjang.

3. Pengumuman buyback berpengaruh positif terhadap volume perdagangan saham dalam jangka pendek

4. Pengumuman buyback berpengaruh positif terhadap volume perdagangan saham dalam jangka waktu yang lebih panjang.

5. Abnormal return sebelum pengumuman buyback berbeda dengan abnormal return sesudah pengumuman buyback.

6. Volume perdagangan sebelum pengumuman buyback berbeda dengan volume perdagangan sesudah pengumuman buyback.

\section{Keterbatasan dan Saran}

1. Dari sekian banyak perusahaan yang terdaftar di Bursa Efek Indonesia, hanya sedikit perusahaan yang mengumumkan akan melakukan buyback. Total sampel yang sedikit ditambah lagi ada beberapa perusahaan yang tidak dapat diakses tanggal pengumuman buyback sehingga mengurangi jumlah sampel yang diuji dalam penelitian ini.

2. Penelitian ini hanya menguji reaksi pasar atas pengumuman buyback, oleh sebab itu penting untuk melihat reaksi pasar atas realisasi pengumuman buyback tersebut.

3. Penelitian selanjutnya dapat membandingkan reaksi pasar bagi perusahaan yang mengumumkan buyback dengan perusahaan yang tidak mengumumkan buyback. 
4. Penelitian ini menggunakan event study untuk melihat reaksi pasar atas pengumuman buyback. Penelitian lain terkait pengumuman buyback mungkin dapat menganalisis faktor-faktor yang mempengaruhi perusahaan melakukan buyback, sehingga dapat diketahui motivasi perusahaan mengumumkan buyback saham.

\section{DAFTAR PUSTAKA}

Agrawal, Anup, J. F. Jaffe dan G. N. Mandelker. 1992. The Post-Merger Performance of Acquiring Firms: A Re-examination of an Anomaly. The Journal of Finance Vol. XLVII, No. 4

Asquith, Paul dan D. W. Mullin.1986. Signalling with Dividends, Buyback, and Equity Issues. Financial Management Journal, Vol. 15, No. 3 pp. $27-44$

Axelsson, Lars dan P. Brissman. 2011. Buyback Announcements and Abnormal returns for Swedish Listed Real Estate Companies. Thesis, Department of Real Estate and Construction Management Stockholm

Baker, H. Kent, G. E. Powell. dan E. T. Veit 2003. Why Companies Use Open-Market Repurchases: A Manajerial Perspective. The Quarterly Review of Economics and Finance 43, 483-504

Barron, Orie E. dan J.M. Karpoff. 2004. Information Precision, Transaction Cost, and Trading Volume. Journal of Banking and Finanace 28, 1207-1223

Boudry, Walter I., J. G. Kallberg, dan C. H. Liu. 2013. Investment Opportunities and Buyback. Journal of Corporate Finance 23, 23-38

Chua, Jian Ming. 2010. Corporate Governance and Earnings Management Before Buyback Announcements in Singapore. Thesis, Singapore Management University

Dixon, Rob, G.Palmer, B. Stradling dan A. Woodhead. 2008. An Emperical Survey of the Motivation for Buyback in the UK. Managerial Finance Vol.34 No.12, 886-906

Gumanti, Tatang A. 2009. Teori Sinyal dalam Manajemen Keuangan. Usahawan No.06 XXXVIII

Haw, In-Mu, S. S. M. Ho, B. Hu dan X. Zhang. 2011. The Contribution of Buyback to the Value of the firm and Cash Holdings Around the World. Journal of Corporate Finance 17, 152-166

Husnan, Suad. 2005. Dasar-Dasar Teori Portofolio dan Analisis Sekuritas. Yogyakarta: UPP AMP YKPN 
Ikenberry, David, J. Lakonishok dan T. Vermaelen. 1995. Market Underreaction to Open Market Buyback. Journal of Financial Economics 39 (1995) 181-208

Ikenberry, David dan T. Vermaelen. 1996. The Option to Repurchase Stock. Financial Management, Vol. 25 No.4, 9-24

Jagannathan, Murali, C. P. Stephens dan M. S. Weisbach. 2000. Financial Flexibility and The Choice Between Dividends and Buyback. The Journal of Finance Economics 57, 355-384

Jogiyanto. 2012. Pasar Efisien Secara Informasi, Operasional, dan Keputusan. Yogyakarta : BPFE Universitas Gadjah Mada

Kim, Oliver dan R.E. Verrecchia. 1991. Trading Volume and Price Reactions to Public Announcements. Journal of Accounting Research Vol. 29 No.2

Lakonishok, Josef dan T. Vermaelen. 1990. Anomalous Price Behavior Around Repurchase Tender Offers. The Journal of Finance Vol. Xlv, No. 2

Lee, Chun I., D. D. EJara dan K. C. Gleason. 2010. An Empirical Analysis of European Stock Repurchases. Journal of Multinational Financial Management 20, 114-125

Lee, Yong-Gyo, S. C. Jung dan J. H. Thornton Jr. 2005. Long Term Stock Performance After Open Market Repurchases in Korea. Global Finance Journal 16, 191-209

Loughran, Tim dan J. R. Ritter. 1997. The Operating Performance of Firms Conducting Seasoned Equity Offerings. The Journal of Finance Vol.LII, No. 5

Malinowska, Magdalena. 2010. Price and Trading Response to Public Information. Working Paper Series No. 1177

Paulsen, Lars Manor. 2011. Do share buyback create value for the shareholders?. Cand.merc Finance \& Strategic management at Copenhagen Business School

Peraturan Nomor XI.B.2 : Pembelian Kembali Saham Yang Dikeluarkan Oleh Emiten Atau Perusahaan Publik. www.bapepam.go.id

Peraturan Nomor XI.B.3 : Pembelian Kembali Saham yang Dikeluarkan oleh Emiten atau Perusahaan Publik dalam Kondisi Pasar yang Berpotensi Krisis. www.bapepam.go.id

Ritter, Jay R. 1991. The Long-Run Performance of Initial Public Offerings. The Journal of Finance Vol. XLVI No. 1 
Wang, Li-Hsun, C. H. Lin, H. G. Fung dan H. M. Chen. 2013. An Analysis of Buyback in Taiwan. International Review of Economics and Finance 27, 497-513

Yanti, Firga. 2012. Pengujian Abnormal return Saham Sebelum dan Sesudah Peluncuran Indeks Saham Syariah Indonesia (ISSI). Jurnal Manajemen, Vol 1, N0.01

Yook, Ken C. 2010. Long-run Stock Performance Following Buyback. The Johns Hopkins Carey Business School.

Zhang, Hua. 2005. Price Performance Following Actual Buyback. Journal of Banking and Finance 29, 1887-1901 